\title{
The Perception of Green Facades and its Effects on Public Spaces' Users
}

\section{A Percepção de Fachadas Verdes e seus Efeitos em Usuários de Espaços Públicos}

Olavo Avalone Neto, Federal University of Santa Maria, Brazil. olavo.neto@ufsm.br

Saori Kihara, N.T.T. Facilities, Kyushu, Japan.

saori.kihara@gmail.com

Jun Munakata, Chiba University, Japan.

munakata@faculty.chiba-u.jp

\begin{abstract}
This article addresses people's perceptions and evaluations of green facades in public settings across nineteen evaluation scales. It uses exploratory methods to investigate people's personal constructs when evaluating green facades and uses statistical models to test two factors - design and plant color - addressing those personal constructs.

Through immersive virtual environments, it explores whether people see green facades as an improvement to public spaces. The study measures the effects of different facade designs and plant colors on the perception of the facade itself and the public spaces in which they are placed. The effects of users' stated predisposition towards green facades and the effects of sex are also tested.

A compound evaluation grid structure of nineteen participants is provided. The results presented may aid urban designers in improving green facades' design and implementation.
\end{abstract}

Keywords: Green Façade, Design, Plant Color, Public Space, Evaluation Grid Method.

\section{Resumo}

Este artigo aborda a percepção e avaliação de fachadas verdes por usuários em ambientes públicos em 19 escalas de avaliação. Utiliza métodos exploratórios para investigar as construções pessoais adotadas pelos usuários ao avaliar fachadas verdes e métodos estátísticos para testar dois fatores - desenho e coloração da planta - relacionados as construções pessoais.

Utiliza ambientes virtuais imersivos para investigar se os usuários consideram fachadas verdes como uma melhoria ao espaço público e mensura os efeitos de diferentes desenhos e coloração da vegetação na percepção da fachada e do espaço público na qual ela se insere. Os efeitos da pré-disposição em relação a fachadas verdes e os efeitos de sexo também são testados.

Uma estrutura composta da matriz de avaliação de construções pessoais de dezenove participantes é fornecida. Os resultados apresentados podem auxiliar urbanistas, arquitetos e designers no desenho e implementação de fachadas verdes.

Palavras-chave: Fachadas Verdes, Design, Coloração da Vegetação, Espaço Público, Matriz de Avaliação de Construções Pessoais. 


\section{Introduction}

Studies of green facades have focused on its potential environmental effects, such as mitigating the heat island effect or reducing noise in residential settings, and the possible effects on the buildings they are attached to, such as reducing the building's thermal load or improving sound insulation. This study proposes to explore the psychological effects of green facades, how passers-by perceive them, how they may improve urban environments, and affect public space usage. A mixed methodology is adopted, using an exploratory survey to elicit participants' evaluation constructs for green facades and an experiment with statistical analysis to assess the most significant constructs' effects. The results offer public space designers recommendations for green facade implementation in urban settings.

\section{Background}

Green facades or living wall systems (L.W.S.) can improve the well-being in and around a building. It can reduce heat loss and absorption by the building envelope, saving energy in heating and cooling (ALEXANDRI; JONES, 2008; COMA et al., 2017; TUDIWER; KORJENIC, 2017; YANG et al., 2018). It offers an improvement to the building envelope's acoustic insulation (AZKORRA et al., 2015; DAVIS et al., 2017; PÉREZ et al., 2016) and increases property value (GAO; ASAMI, 2007; PECK et al., 1999; PERINI; ROSASCO, 2013; DES ROSIERS et al., 2002). Houses with vegetation integrated into the buildings are more preferred, beautiful, restorative, and have a more positive affective quality than houses without (WHITE; GATERSLEBEN, 2011).

On an urban scale, green facades provide a range of ecological and environmental benefits such as increasing biodiversity (COLLINS; SCHAAFSMA; HUDSON, 2017; MADRE et al., 2015), improving air quality, and reducing pollution levels (GROMKE; JAMARKATTEL; RUCK, 2016; JAYASOORIYA et al., 2017; OTTELÉ; VAN BOHEMEN; FRAAIJ, 2010; PUGH et al., 2012), mitigating urban heat island effect (ALEXANDRI; JONES, 2008), mitigating noise levels in buildings' courtyards (VAN RENTERGHEM et al., 2013; VEISTEN et al., 2012) and traffic noise reduction (LACASTA et al., 2016; LUNAIN; ECOTIERE; GAUVREAU, 2016).

Overall, green spaces are known to promote mental and physical health (HEDBLOM et al., 2019) and improve façade aesthetics (WHITE; GATERSLEBEN, 2011), but little attention has been given to the potential psychological effects of green facades on users of contiguous spaces such as streets or urban plazas. As they change the buildings' aesthetics, green facades can affect users' perceptions and impressions of the adjacent public spaces, making them more suitable for specific activities and improving the urban environment. This study uses an exploratory survey to identify which characteristics of green facades are most considered by public space users. It then uses that information to test the specific effects of some of those characteristics in public space perception, impressions, and perceived suitability for several activities.

\section{Methods}


First, this study identifies which aspects of green facades are most valued by public space users so that the actual effects of those characteristics could be tested in a controlled setting. For this purpose, an evaluation grid method (E.G.M.) survey was conducted.

Once the aspects most perceived and valued by users were identified, a second experiment used those characteristics as variables and tested their effects on users' perceptions and impressions of public spaces. The survey used semantic differential questionnaires and evaluated ten different immersive virtual environments (I.V.E.).

\section{First Survey}

To understand how green facades are considered and valued by public space users, an E.G.M. survey was conducted between July $1^{\text {st }}$ and $31^{\text {st }}$ of 2016 , and the stimuli consisted of 30 examples of green facades in different settings but observed from similar vantage points. Stimuli were acquired through Google Earth (Figure 1) and presented in printed, A7 format. There were 19 participants, ten male, and nine female, all Japanese architecture students between 18 and 23 years $(\mathrm{M}=22.68 ; \mathrm{SD}=0.80)$.

E.G.M. is derived from Kelly's (1955) personal construct theory and is designed to elicit participants' personal constructs from differences among elements (stimuli). It focuses on the constructs people use specifically to evaluate the environment and uses leading questions to elicit higher and lower level constructs related to those initial constructs, avoiding a flattening design (SANUI, 1996).

This method can be applied to one or a group of participants at once. Although submitting the survey individually to each participant is more labor-intensive, it tends to yield better results since participants in a group may restrain from expressing personal constructs that are too different from their peers. Therefore, participants were surveyed individually.

Participants were asked to sort and divide the stimuli into five groups, from those they preferred the most to the least preferable. The instruction given was: "please divide these 30 types of green facades into five groups and arrange the groups by preference, as you were an observer walking in the street. Groups may have as much or as little facades as you desire."

Once the sorting was done, the interviewer asked the participant why the second least preferred group was better than the least preferred group. Once the participant has exhausted his/her reasons, the interviewer moves to the next group and the next until all five groups are covered. The answers given by participants are noted in a central column as the 'original constructs.' Participants are encouraged to elicit reasons both for differences between groups as a whole and from differences between any two specific stimuli present in those groups.

The interviewer then asked the participant about each 'original construct' given by him/her, in the following manner: "you said that being " $X$ " was good, why do you think it is good?" which elicited participants to explain further the impressions they hope to feel or value (laddering up). At last, for each 'original construct' given, the participant was asked: "you said that being " $X$ " was good. What, specifically, makes it good?" which elicited participants to think about the particular aspects of the environment that pleased them and made the environment more or less preferable (laddering down). 

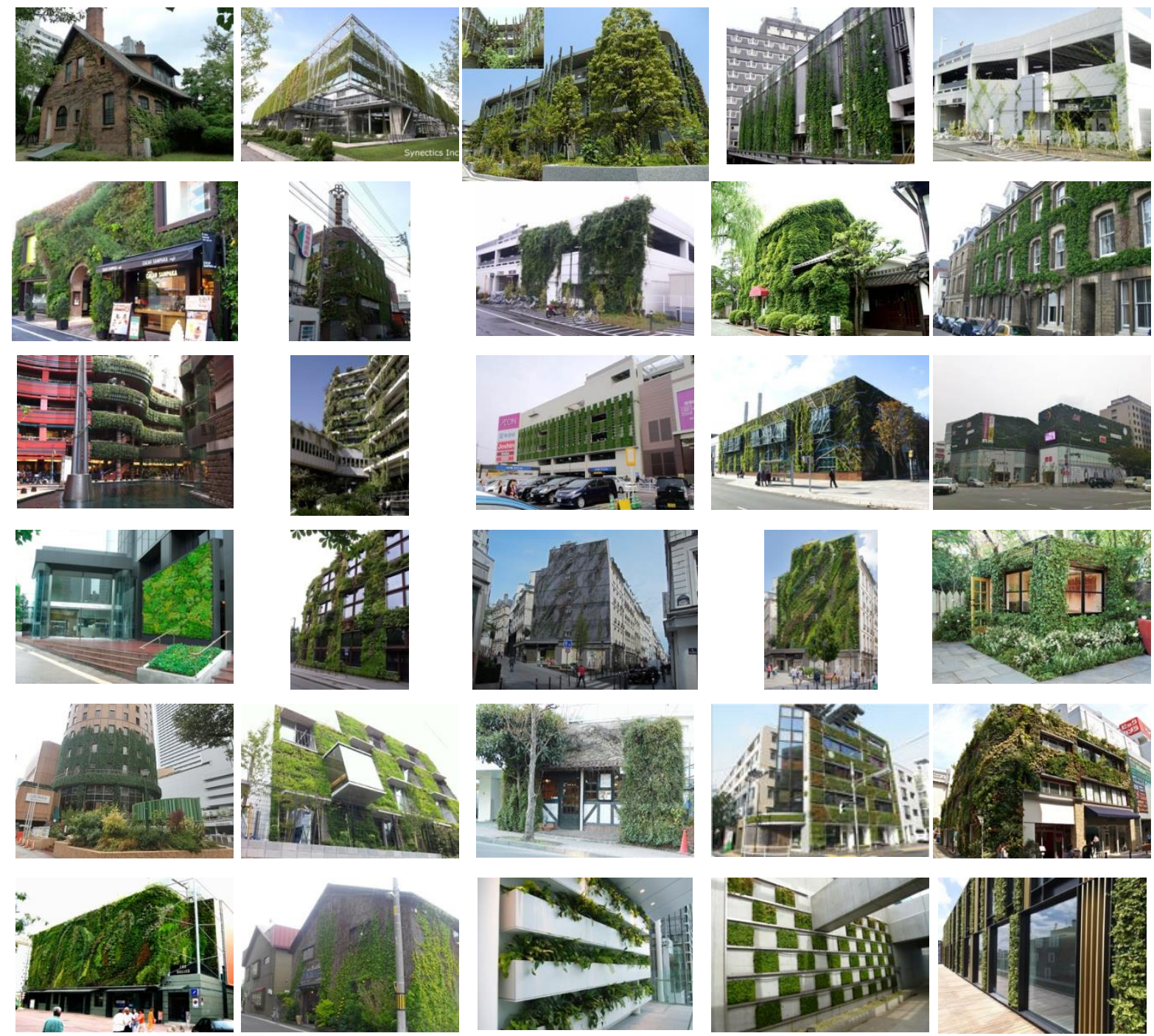

Figure 1 - Stimuli of the E.G.M. survey.

As participants were asked about the differences between stimuli, they sometimes expressed it negatively rather than in positive terms (e.g., "stimulus B looks dirtier than stimulus A"). The interviewer would then ask a clarification in a positive rather than negative phrasing (e.g., "so, $A$ is preferable than B because A is cleaner than B, is that so?").

Each participant's answers were then organized into a hierarchical network structure with higher constructs to the left, original constructs in the middle, and lower constructs to the right. Lower constructs reflect more concrete aspects of the environment, while higher constructs are closer to impressions or emotions. Sometimes, participants answered lower or higher constructs as original ones, making it impractical to conduct the appropriate laddering questions. These constructs were later reorganized either to the left or right so that the structure could be easily readable.

The structure was simplified, higher and lower constructs were sorted, and overlapping statements were eliminated, with the connection between different statements preserved. At last, the evaluation structure of all participants was compounded into a single hierarchical network diagram (Figure 2). 
Results

Participants' evaluations were mainly focused on environmental cleanliness, comfort, and maintenance. Regarding the green wall, thick and three-dimensional plants were preferred. Those environmental aspects were related to a feeling of relaxation, safety, pleasurable experience, fun/excitement, motivation, and wanting to enter the building (higher constructs), as shown in Figure 2 and Table 1.

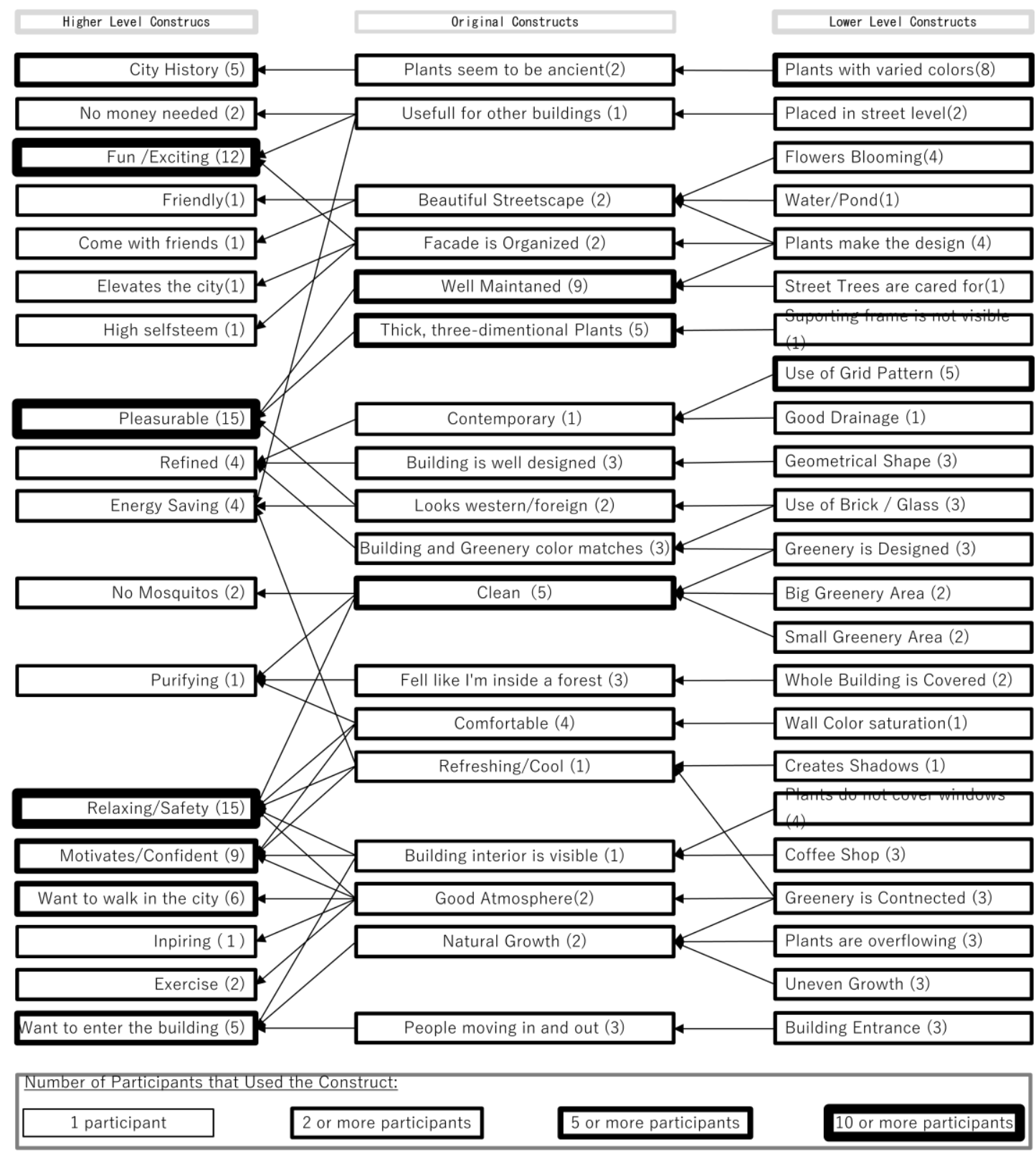

Figure 2 - Compound Evaluation Grid Structure.

Environmental evaluations were based on physical aspects of the environment, on three distinct categories: regarding the building and the environment (material and color of the facade, building design and use, and surrounding greenery), regarding the greenery development (wall cover ratio, plant volume, and growth) and space plan and management (plant species, greenery design, maintenance, shape/form, placement and planting conditions) (Table 2). 


\begin{tabular}{l|l}
\hline Category & Value/Aspect \\
\hline Users & Relaxing / Safety \\
& Optimistic feeling \\
& Fun / exciting \\
& Happiness/Well-being \\
& Usefulness \\
\hline Building & Historic feeling \\
& Refreshing / Cool \\
& Stylish \\
\hline Human Involvement & Planned / Accidental \\
& Natural / Artificial \\
\hline Relation to the building & In harmony/discord \\
Relation to the surroundings & In harmony/discord \\
\hline
\end{tabular}

Table 1 - Most expressed constructs regarding Green Facades.

\begin{tabular}{l|l|l}
\hline Category & Subgroup & Value/Aspect \\
\hline Building and & Design/use & Historic feeling, building use \\
Surrounding & Facade material & The facade is glass or brick \\
Environment & Facade color & Color, illumination \\
& Amount of surrounding greenery & Presence/absence of trees in the street \\
& Surrounding condition & Presence/absence of water \\
\hline Greenery & Greening Scope & The whole or partially covered wall \\
Development & Volume & Even / uneven thickness \\
& Growth development & Plants are growing untouched. \\
\hline Plan & Species & Is there a variety of species? \\
Management & Design/use & Was it intentionally designed with the wall \\
& Maintenance & Are the plants being well maintained \\
& Shape/Form & Is it contained within a frame \\
& Planting Condition & Growing up or sagging \\
& Placement & It is planted in which part of the building \\
\hline
\end{tabular}

Table 2 - Constructs regarding the design and execution of the green facades.

\section{Discussion}

Based on the network structure of the 19 participants, green facade design can affect users' perception due to its design (the relation to the openings, use of a grid pattern, plant and building colors) and maintenance (even/uneven growth, wall coverage, plants thickness).

Although we know those aspects are considered in environment evaluation, the extent of these effects is still unclear. For instance, while several participants state that a clean environment is desirable, some state that extensive facade coverage leads to a clean environment, while others say that a small coverage area achieves a clean environment. Designers may use the hierarchical network to improve the design (e.g., implement grid pattern designs with flowers blooming), but its usage is limited to the consciously stated constructs. The extent of the effect of specific design choices such as greenery thickness, greenery color, design pattern, amongst others, may be further investigated through statistical analysis.

Based on the participants' evaluation grid structure, two hypotheses were constructed regarding green facade design and plants color:

H1: A structured, organized design is preferable over freer unstructured ones.

H2: Colorful plant cover is preferred over flat green ones.

\section{Second Survey}


Based on the E.G.M. survey results, the specific effects of greenery color and design pattern were tested. Greenery and building color appeared in original and physical element constructs (plants with varied colors, brick/glass use, building, and greenery color matches). In contrast, the design pattern appears in constructs related to form (greenery is designed, use of grid pattern) and plant coverage/thickness (greenery is connected, uneven growth, overflowing, plants make the design).

According to Perini et al. (2011) and Manso \& Castro-Gomes (2015), a distinction can be made between green facades and living wall systems (L.W.S.): while in green facades, the plants are rooted in the ground or in the wall material itself, L.W.S. uses modular panels with a substrate attached to the wall. For psychological purposes, not the implementation method, but the visual aspect each method provides is essential. The second experiment considered how green facades are commonly implemented with three different designs: a flat pattern with delimited plant growth (e.g., well maintained direct greening system), a grid pattern with some plant growth (e.g., L.W.S. with foam substrate), and a wave pattern with a lot of plant growth (e.g., L.W.S. based on felt layers). The stimuli adopted are shown in Table 3.

\begin{tabular}{cccc}
\hline & Green & Red & Yellow \\
\hline Flat pattern - trimmed & S01 & S02 & S03 \\
Grid pattern - trimmed & S04 & S05 & S06 \\
Wave pattern - untrimmed & S07 & S08 & S09 \\
\hline
\end{tabular}

Table 3 - Stimuli matrix.

Based on the hypotheses, a preference for the grid, flat, and then wave designs were expected, as was the preference for designs with red and yellow plants over all-green designs.

A virtual environment of each stimulus was created in SketchUp and rendered in Unity software. The stimuli were presented to participants through an Oculus-rift head-mounted display (H.M.D.), which immersed participants in the virtual environment. Through the H.M.D., participants visually experienced the environment as they would in a natural setting. Participants were seated during the experiment, but they were able to simulate walking through the use of a Logicool gamepad F110.

Immersive virtual environments (I.V.E.) allow for high experimental control while preserving mundane realism (BLASCOVICH et al., 2002). The use of I.V.E. to evaluate public settings using H.M.D. has been validated in a previous study (AVALONE NETO et al., 2016) and can obtain results similar to natural environment evaluations.

Participants experienced each environment for about 3 minutes, removed the H.M.D. and answered a printed questionnaire. If needed, participants were allowed to wear the H.M.D. again to experience the virtual environment further while answering the questionnaire. There was 1 minute of eye rest between each stimulus. Participants first evaluated the space without any green facade (top of Figure 3) and then assessed the nine stimuli with the green wall (Table 3 and Figure 3), presented in random order. 

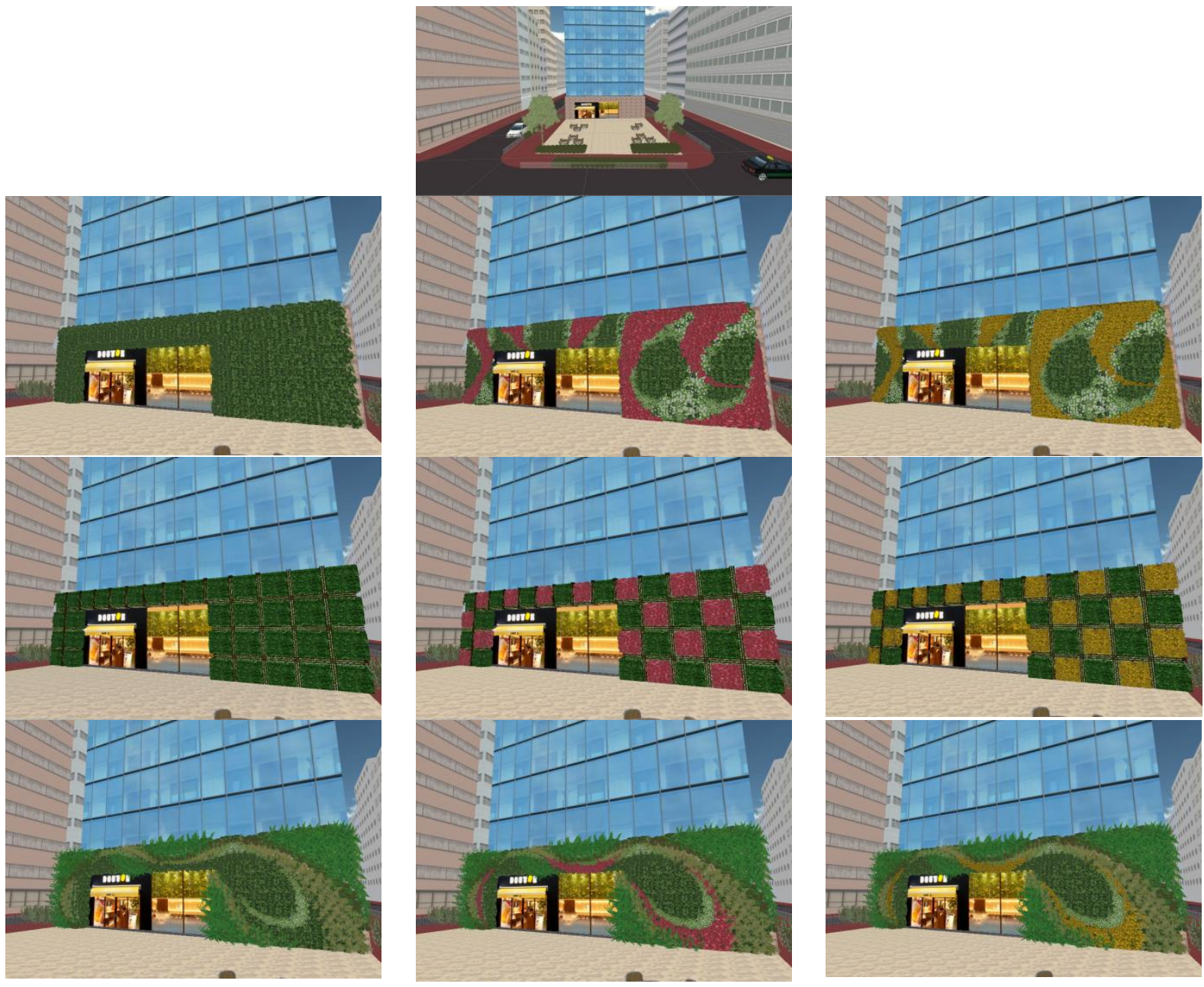

Figure 3 - Stimuli used for the I.V.E. survey.

The environment without a green facade is shown on top. Stimulus 1 to 9 are shown from left to right and top-down.

A questionnaire using semantic differential (S.D.) questions was adopted to assess people's attitudes toward the different green facades. The method was first proposed by Osgood, Suci, and Tannenbaum in 1957 and offers a relatively easy method to administer, have good reliability, and allow for a clear distinction between positive/neutral and positive/negative scales (e.g., not bright/ bright and dark/bright) and consequently a more refined nuance to participants responses than other evaluation scales such as Thurstone's equal-appearing intervals or Likert's summated rating method (Krosnick Judd \& Witternbrink, 2005).

In an S.D. scale, each question consists of a pair of antonyms adjectives placed at the extreme of a 7 point evaluation scale, comprising an evaluative dimension. For each dimension, the participant assesses his attitude toward the object by selecting which point along the scale they identify as the correspondent to their evaluation (Krosnick; Judd; Witternbrink, 2005).

This method also has the advantage of being widely used in people-environment research (Krosnick; Judd; Witternbrink, 2005).

The questionnaire had 19 evaluation scales divided into three categories: perceived suitability of the public square for different activities, with five assessment scales (stay, eat/drink, rest, wait and read), perception of the public square adjacent to the green wall, with nine assessment scales (how inviting was the shop entrance, comfort, appearance, atmosphere, organization, intimacy, safety, refinement, and engagement), and perception of the green wall 
itself, with five assessment scales (maintenance, greenery amount, artificialness, design, and engagement). The evaluation scales can be seen in Tables 5 and 6 .

The activity-related scales' expand on a more extensive study that seeks to identify environmental characteristics that may afford different activities (AVALONE et al., 2017) and where perception may be conditioned to intent.

The scales related to public square perception aim to identify the effects of the green wall in the adjacent public space in different dimensions, while the scales related to the green facade itself address stated personal constructs and their relation to wall design.

The scales were not statistically validated for this study, but they have been used in research that related actual public space to virtual public space impression (AVALONE et al., 2016), finding similar results. It should be noted that the measurement is made by comparison of values of different stimuli and not the actual measured value, meaning that eventual errors of meaning interpretation in a measurement scale will be equally distributed across all stimuli and should not skew the results. Also, the research was conducted in the Japanese language, and that there may be some translation nuances.

At the end of the questionnaire, participants were asked whether they liked green facades, if they wish there to be more of them in the cities, and why. Based on their answers, participants were separated into three groups: favorable, neutral, and unfavorable to green facades, and the results were tested for the effect of their predispositions.

There were 26 participants (13 female and 13 male) in this survey, all Japanese and architectural students between 20 and $23(\mathrm{M}=21.65 ; \mathrm{SD}=0.68)$.

The effects of green wall presence/absence, green facade design and color, and the effects of gender were tested through analysis of variance (ANOVA).

The presence/absence of green facade was used as predictors to the evaluation scales to test the effect of green facade presence in public square perception.

A second analysis tested green facade and color variation as predictors to the evaluation scales. At last, gender was also included as a variable to test for its effect.

\section{Results}

The mere presence of a green facade improved suitability for 'read' activity, improved intimacy, spatial refinement, engagement, and worsened the environment's perceived organization (Table 4).

The design of the Green Facade did not affect perceived environmental suitability to perform different activities. The same could be said for plant colors, except 'wait' activity, which had a small effect (Table 4). For the 'wait' activity, red and yellow plants were equally preferable over green ones.

The green façade's design affected the perception of the environments' organization. Environments that adopted the grid pattern were perceived as more organized than both flat and waved patterns, regarded as similar (Table 4 and 5).

Plant color affected the environments' atmosphere, and environments with red or yellow plants were perceived as more refined than those with only green ones (Table 6). 


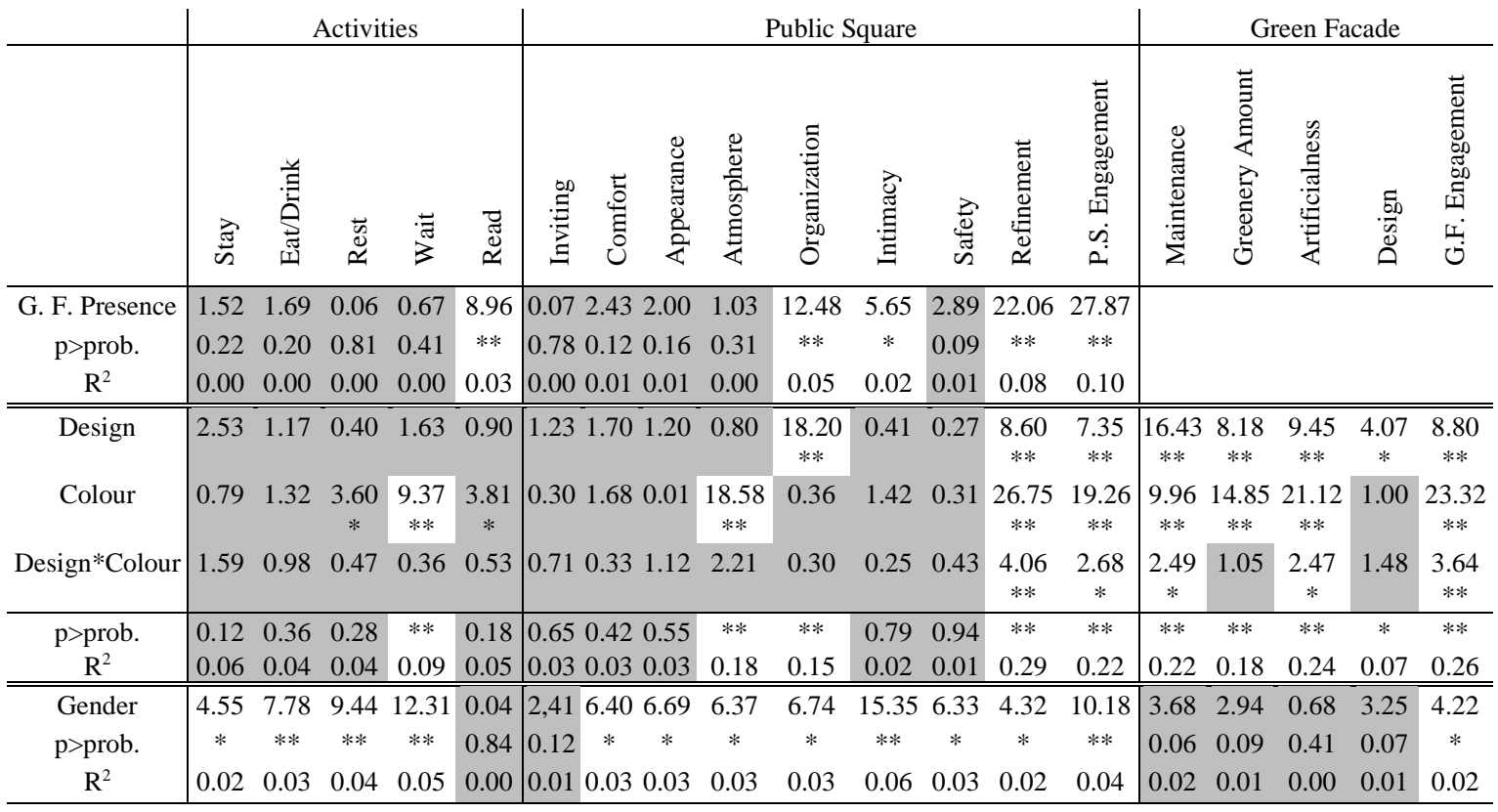

Table 4 - Summary of the Effects of Green Facade Presence and effects of Design and Plant Color.

Note: This table summarizes three different analyses with the statistical validity of each model. The analyses are (from top to bottom): effect of green wall presence/absence, effects of design and color, and the effects of gender. Double lines separate the analyses. The values expressed in the upper part of the table are $F(1,258)$; in the middle part of the table are $F(2,225)$ and in the lower part of the table are $F(1,232) ; * *=\mathrm{p}<.001 ; *=\mathrm{p}<.05$.

The public square refinement and engagement were affected by both the facade design and plant color. Squares that adopted the wave design were perceived as more refined and engaging than those with flat or grid patterns, and environments where plants had either red or yellow, as opposed to green color, were also perceived as more refined and engaging. The interaction between design and plant color also had an effect: while red and yellow colored plants had similar ratings for all three designs when plant color was green, there was a clear preference of grid over flat pattern and wave over a grid pattern (Table 4, Figures 4 and 5).

Regarding the green facade's perception, grid pattern design was perceived as better maintained than flat or wave design. Plants with red or yellow color were also perceived as better maintained than those with green color. Interactions between design and color could be seen for maintenance, and while the flat design was perceived as better than the wave design for facades with red and yellow plants, it received similar evaluations when it had only green plants (Table 4 and Figure 6).

The wave design was perceived as having more greenery than flat or grid designs, which had similar scores, and plants with only green color were perceived as having more greenery than when plants had either yellow or red-colored plants.

Designs with a grid pattern were perceived as more artificial than flat or wave designs, and green colored plants were perceived as more natural than either yellow or red ones. Interaction between design and color could be observed, and flat, green designs were perceived as the more natural (Figure 7). The wave design was perceived as better than the flat design, while the grid design was perceived as no different from either wave or flat.

Facades with wave design were perceived as more engaging, as were those with greencolored plants. However, the interaction between design and plant color made flat and green designs to be perceived as the least engaging of them all (Figure 8). 


\begin{tabular}{|c|c|c|c|c|c|c|c|c|}
\hline & -3 & -2 & -1 & 0 & 1 & 2 & 3 & \\
\hline Unsuitable for Waiting & & & & & $\mathrm{x} \bullet \approx$ & & & Suitable for Waiting \\
\hline Unsuitable for Staying & & & & $\mathrm{x}$ & $\square \approx$ & & & Suitable for Staying \\
\hline Unsuitable for Eat/Drinking & & & & $\mathrm{x} \bullet$ & $\mathbf{a} \approx$ & & & Suitable for Eat/Drinking \\
\hline Unsuitable for Resting & & & & $\mathrm{x}$ & $\bullet$ & & & Suitable for Resting \\
\hline Unsuitable for Reading & & & $x \bullet \square$ & & $\approx$ & & & Suitable for Reading \\
\hline Uncomfortable & & & & $\mathrm{x}$ & - & & & Comfortable \\
\hline Not an Intimate Environ. & & & $\mathrm{x}$ & - & $\approx$ & & & An Intimate Environ. \\
\hline Do not feel like entering & & & & $\mathrm{x}$ & - $\approx$ & & & Feel like entering \\
\hline An ugly place & & & & $\mathrm{x}$ & $\bullet \approx \approx$ & & & Beautiful place \\
\hline Messy Environment & & & $\approx \bullet$ & & $\mathbf{m}$ & & & Orderly Environment \\
\hline Feel Anxious & & & $\mathrm{x}$ & $\bullet$ & $\approx$ & & & Feel Safe \\
\hline Boring Plaza & & $\mathrm{x}$ & & $\bullet$ & $\approx$ & & & Joyful Plaza \\
\hline Gloomy atmosphere & & & & $\mathrm{x}$ & $\bullet \approx$ & & & Cheerful atmosphere \\
\hline Plain & & & $\mathrm{x}$ & $\bullet$ & - $\approx$ & & & Refined \\
\hline Poorly Maintained & & & & & $\approx \bullet$ & 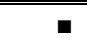 & & W Well Maintained \\
\hline Bad design & & & & $\bullet$ & $\approx$ & & & Good Design \\
\hline Boring Facade & & & & & - $\approx$ & & & Joyful Facade \\
\hline Little Greenery & & & & & $\bullet$ & $\approx$ & & A lot of Greenery \\
\hline Artificial & & - $\approx$ & $\bullet$ & & & & & Natural \\
\hline
\end{tabular}

Table 05 - Mean Score of Design pattern $\mathrm{x}$ Wall facade (no greenery) $\bullet$ Flat $\square$ Grid $\approx$ Wave

\begin{tabular}{|c|c|c|c|c|c|c|c|c|}
\hline & -3 & -2 & -1 & 0 & 1 & 2 & 3 & \\
\hline Unsuitable for Waiting & & & & & $\mathrm{x} \bullet \bullet \bullet$ & & & Suitable for Waiting \\
\hline Unsuitable for Staying & & & & $\mathrm{x}$ & $\bullet \bullet$ & & & Suitable for Staying \\
\hline Unsuitable for Eat/Drinking & & & & $\mathrm{x} \bullet$ & $\bullet$ & & & Suitable for Eat/Drinking \\
\hline Unsuitable for Resting & & & & $\mathrm{x} \bullet$ & $\bullet$ & & & Suitable for Resting \\
\hline Unsuitable for Reading & & & $\mathrm{x} \bullet$ & $\circ$ & $\bullet$ & & & Suitable for Reading \\
\hline Uncomfortable & & & & $\mathrm{x} \bullet$ & $\bullet \bullet$ & & & Comfortable \\
\hline Not an Intimate Environ. & & & $\mathrm{x}$ & $\bullet$ & $\bullet$ & & & An Intimate Environ. \\
\hline Do not feel like entering & & & & $\mathrm{x}$ & $\bullet \bullet \bullet$ & & & Feel like entering \\
\hline An ugly place & & & & $\mathrm{x}$ & $\bullet \bullet$ & & & Beautiful place \\
\hline Messy Environment & & & & & $\bullet \bullet x$ & & & Orderly Environment \\
\hline Feel Anxious & & & $\mathrm{x}$ & & $\bullet \bullet$ & & & Feel Safe \\
\hline Boring Plaza & & & $x$ & & $\bullet$ & & & Joyful Plaza \\
\hline Gloomy atmosphere & & & & $\bullet$ & $\mathrm{x} \bullet \bullet$ & & & Cheerful atmosphere \\
\hline Plain & & & $\mathrm{x} \bullet$ & & $\bullet$ & & & Refined \\
\hline Poorly Maintained & & & & & $\bullet$ & $\bullet$ & & Well Maintained \\
\hline Bad design & & & & - & $\infty$ & & & Good Design \\
\hline Boring Facade & & & - & & $\bullet$ & & & Joyful Facade \\
\hline Little Greenery & & & & & $\bullet \quad-$ & - & & A lot of Greenery \\
\hline Artificial & & $\bullet$ & - & & & & & Natural \\
\hline
\end{tabular}

Table 06 - Mean Score of Plant Color

x Wall facade (no greenery) •Green •Red $\bullet$ Yellow

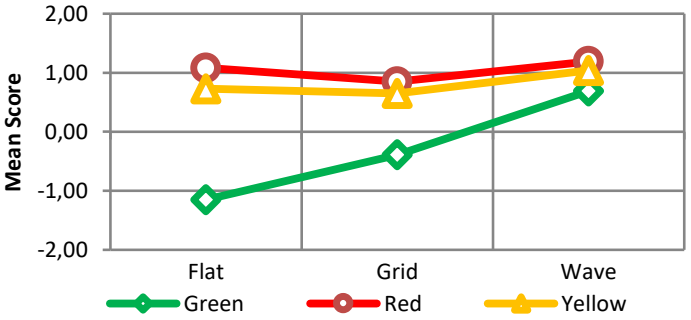

Figure 4 - Effects on P. S. Refinement Perception

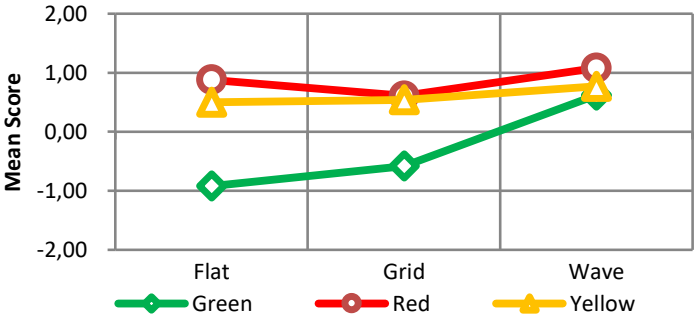

Figure 5 - Effects on P. S. Engagement Perception 


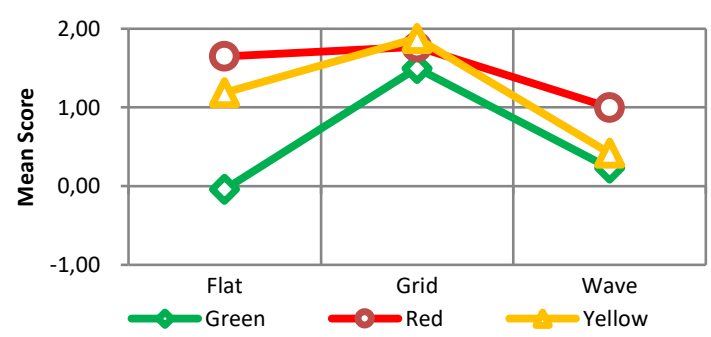

Figure 6 - Effects on Maintenance Perception

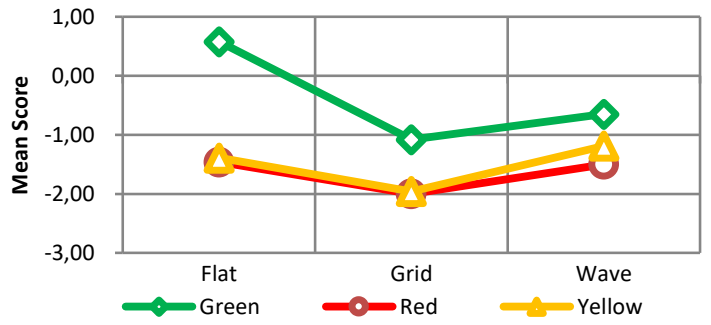

Figure 7 - Effects on Perception of Artificialness

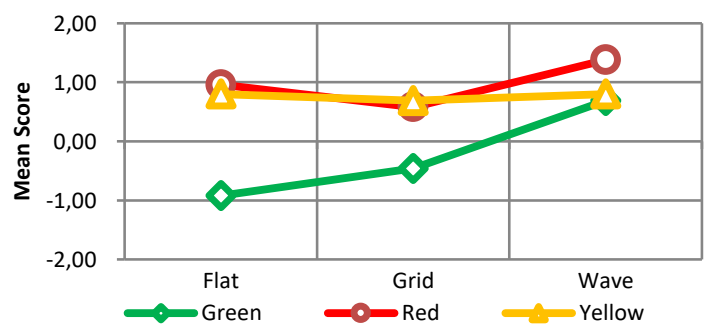

Figure 8 - Effects on Facade Engagement

Of the 26 participants, four stated a negative predisposition, five had a neutral predisposition, and 17 said they had a favorable predisposition to green facades. Participants' predispositions did have a small effect on 'rest' activity $\left(\mathrm{R}^{2}=.02, F_{(2,231)}=3.33, \mathrm{p}<.05\right)$, environmental appearance $\left(\mathrm{R}^{2}=.03, \quad F_{(2,231)}=3.28, \mathrm{p}<.05\right)$, organization $\left(\mathrm{R}^{2}=.04, F_{(2,231)}=5.21, \mathrm{p}<.01\right)$ and perceived artificialness $\left(\mathrm{R}^{2}=.07, F_{(2,231)}=9.15, \mathrm{p}<.001\right)$, but participants who reported a neutral predisposition for green facades scored more than both favorable and unfavorable participants in all of these scales. Participants with either favorable or unfavorable predispositions made similar evaluations.

An effect of gender could be seen in stay, eat/drink, rest, wait activities, comfort, appearance, atmosphere, organization, intimacy, safety, refinement and engagement, and the facade engagement perception. On all scales where a gender effect could be observed, women evaluated the environment more favorably than men (Table 4).

\section{Discussion}

Green facade design had no effect on perceived suitability for different activities nor plant color, except for 'wait' activity. The lack of effect for most activities is probably because green facades do not provide a functional purpose, as would other design elements such as seats, trees (shadows), or a central element (point of reference).

Green facades seem to be most helpful to improve an environments' aesthetics: while there are no effects from facade design or plant color on the perception of how inviting, comfortable, intimate, or safe the environment is perceived, it did affect the perception of the atmosphere, refinement and engagement, while the grid pattern affected the perception or organization.

Participants perceived the grid pattern as a functional design, suitable for maintenance but artificial, while the wave design was perceived as poorly maintained but with a better and more 
joyful design. Finally, flat design, although perceived as the most natural, was unappealing and poorly evaluated overall.

Facades with only green plants were perceived as having more greenery and natural, but facades with red or yellow plants were preferred overall and perceived as better maintained, better designed, and more joyful.

\section{Conclusion and Limitations}

The presence of green facades improves perceived suitability for 'read' activity, the environment's intimacy, refinement, and environment engagement while making the environment less organized.

Contrary to the initial expectations, the wave design was perceived as better than the grid or flat designs. Although participants did cite the grid pattern in the E.G.M. survey, when immersed in an environment with each design, rather than comparing between options, a freer, less constricted design with thicker plants was preferred. Nevertheless, the grid pattern was still preferred over the flat design.

Red and Yellow colors were, indeed, preferred over all-green facades. They improved the perception of the environment and the perception of the facade itself. All green facades were perceived as more natural and having more greenery, but that did not translate into an improved perception of the green facade or the environment.

Green facade design and plant colors had no effect on perceived suitability for different activities, except for a small effect in perceived suitability for wait activity, which does require different environmental characteristics than other activities (Avalone Neto et al., 2017) and is related to visual search, making environments with colorful facades more appealing.

When there is an effect present, stated predisposition towards green facades makes people more critical of the environment resulting in worse impressions, independent of whether the user is favorable or unfavorable to green facades. Conversely, users that do not have a predisposition to green facades tend to evaluate them more favorably.

There was an effect of gender across several scales, and women perceived the environment more favorably, and men seem to judge the environment more harshly than women.

This study was applied to a very restricted age and ethnicity group (Japanese university students in their 20s) and cannot be generalized without further investigations. Differences between architectural students and laypersons may also arise and should be further investigated. Furthermore, the E.G.M. survey may yield different value structures for people from different cultural backgrounds and age groups and should also be tested.

The E.G.M. provided a good understanding of the elements considered by participants when evaluating an environment and provided an evidence-based choice of variables for further quantitative analysis, including testing of conflicting perceptions, such as messy patterns and maintenance. 


\section{References}

ALEXANDRI, Eleftheria; JONES, Phil. Temperature decreases in an urban canyon due to green walls and green roofs in diverse climates. Building and Environment, v. 43, n. 4, p. 480-493, 2008.

AVALONE NETO, Olavo; MUNAKATA, Jun; JEONG, Sinwon; YOSHIDA, Yushi. Public space design effect on users' perceptions, impressions and intended activities. Journal of Environmental Engineering (Japan), v. 82, n. 737, 2017.

AVALONE NETO, Olavo; MUNAKATA, Jun; JEONG, Sinwon; YOSHIDA, Yushi. Evaluating public spaces through immersive virtual environment: real and virtual environments differences. Summaries of Technical Papers of Annual Meeting, Architectural Institute of Japan, 173-174, 2016. https://ci.nii.ac.jp/naid/200000371874.

AZKORRA, Z.; PÉREZ, G.; COMA, J.; CABEZA, L.F.; BURES, S.; ÁlVARO, J. E.; ERKOREKA, A.; URRESTARAZU, M.. Evaluation of green walls as a passive acoustic insulation system for buildings. Applied Acoustics, v. 89, p. 46-56, 2015.

BLASCOVICH, Jim; LOOMIS, Jack; BEALL, Andrew C.; SWINTH, Kimberly R.; HOYT, Crystal L.; BAILENSON, Jeremy N. Immersive virtual environment technology as a methodological tool for social psychology. Psychological Inquiry, v. 13, n. 2, p. 103-124, 2002.

COLLINS, Rebecca; SCHAAFSMA, Marije; HUDSON, Malcolm D. The value of green walls to urban biodiversity. Land Use Policy, v. 64, p. 114-123, 2017.

COMA, Julià; PÉREZ, Gabriel; de GRACIA, Alvaro; BURÉS, Silvia; URRESTARAZU, Miguel; CABEZA, Luiza F.Vertical greenery systems for energy savings in buildings: A comparative study between green walls and green facades. Building and Environment, v. 111, p. 228-237, 2017.

DAVIS, M.J.M; TENPIERIK, M. J., RAMÍREZ, F. R., \& PÉREZ, M. E. More than just a Green Facade: The sound absorption properties of a vertical garden with and without plants. Building and Environment, v. 116, p. 64-72, 2017.

DES ROSIERS, Francois; THÉRIAULT, Marius; KESTENS, Yan; VILLENEUVE, Paul. Landscaping and House Values: an empirical investigation. Journal of Real Estate Research, v. 23, n. 23, p. 139-162, 2002.

GAO, Xiaolu; ASAMI, Yasushi. Effect of urban landscapes on land prices in two Japanese cities. Landscape and Urban Planning, v. 81, n. 1-2, p. 155-166, 2007.

GROMKE, Christof; JAMARKATTEL, Nabaraj; RUCK, Bodo. Influence of roadside hedgerows on air quality in urban street canyons. Atmospheric Environment, v. 139, p. 75-86, 2016.

HEDBLOM, Marcus; GUNNARSSON, Bengt; IRAVANI, Behzad; KNEZ, Igor; SCHAEFER, Martin; THORSSON, Pontus; Lundström, Johan N. Reduction of physiological stress by urban green space in a multisensory virtual experiment. Scientific Reports, v. 9, n. 1, p. 1-11, 2019.

JAYASOORIYA, V. M.; NG, A. W. M., MUTHUKUMARAN, S., \& PERERA, B. J. C. Green infrastructure practices for improvement of urban air quality. Urban Forestry and Urban Greening, v. 21, p. 34-47, 2017.

KELLY, George A. The Psychology of Personal Constructs. New York: Norton, 1955.

KROSNICK, J. A, JUDD, C. M., \& WITTENBRINK, B. (2005). Attitude measurement. In D. ALBARRACIN, B. T. JOHNSON, \& M. P. ZANNA (Eds.), Handbook of attitudes and attitude change. Mahwah, $\mathrm{NJ}$ : Erlbaum.

LACASTA, A. M.; PENARANDA, A.; CANTALAPIEDRA, I. R.; AUGUET, C.; BURES, S.; URRESTARAZI, M. Acoustic evaluation of modular greenery noise barriers. Urban Forestry and Urban Greening, v. 20, p. 172-179, 2016.

LUNAIN, David; ECOTIERE, David; GAUVREAU, Benoit. In-situ evaluation of the acoustic efficiency of a green wall in urban area. Proceedings of the INTER-NOISE 2016 - 45th International Congress and Exposition on Noise Control Engineering: Towards a Quieter Future, p. 6592-6601, 2016.

MADRE, Frédéric; CLERGEAU, Philippe; MACHON, Nathalie; VERGNES, Alan. Building biodiversity: Vegetated façades as habitats for spider and beetle assemblages. Global Ecology and Conservation, v. 3, p. 222-233, 2015.

MANSO, Maria; CASTRO-GOMES, João. Green wall systems: A review of their characteristics. Renewable and Sustainable Energy Reviews, v. 41, p. 863-871, 2015. 
OTTELÉ, Marc; VAN BOHEMEN, Hein D.; FRAAIJ, Alex L.A. Quantifying the deposition of particulate matter on climber vegetation on living walls. Ecological Engineering, v. 36, n. 2, p. 154-162, 2010.

PECK, Steven W.; CALLAGHAN, Chris; KUHN, Monica E.; BASS, Brad. Greenbacks from green roofs. Toronto: Canada Mortgage and Housing Corporation, 1999.

PÉREZ, Gabriel; COMA, Julià; BARRENECHE, Camila; de GRACIA, Alvaro; URRESTARAZU, Miguel. Acoustic insulation capacity of Vertical Greenery Systems for buildings. Applied Acoustics, v. 110, p. 218-226, 2016.

PERINI, Katia; OTTELÉ, Marc; HAAS, E. M.; RAITERI, Rossana. Greening the building envelope, facade greening and living wall systems. Open Journal of Ecology, v. 01, n. 01, p. $1-8,2011$.

PERINI, Katia; ROSASCO, Paolo. Cost-benefit analysis for green façades and living wall systems. Building and Environment, v. 70, p. 110-121, 2013.

PUGH, Thomas A.M.; MACKENZIE, A. Robert; WHYATT, J. Duncan; HEWITT, C. Nicholas. Effectiveness of green infrastructure for improvement of air quality in urban street canyons. Environmental Science and Technology, v. 46, n. 14, p. 7692-7699, 2012.

SANUI, Junichiro. Visualization of users' requirements: Introduction of the Evaluation Grid Method. Proceedings of the Third Design and Decision Support Systems in Architecture and Urban Planning Conference, Vol.1, No.1 (1996).

TUDIWER, David; KORJENIC, Azra. The effect of living wall systems on the thermal resistance of the façade. Energy and Buildings, v. 135, p. 10-19, 2017.

VAN RENTERGHEM, Timothy; HORNIKX, Maarten; FORSSEN, Jens; BOTTELDOOREN, Dick. The potential of building envelope greening to achieve quietness. Building and Environment, v. 61, p. 34-44, 2013.

VEISTEN, Knut; SMYRNOVA, Yuliya; KLAEBOE, Ronny; HORNIKX, Maarten; MOSSLEMI, Marjan; KANG, Jian. Valuation of green walls and green roofs as soundscape measures: Including monetized amenity values together with noise-attenuation values in a costbenefit analysis of a green wall affecting courtyards. International Journal of Environmental Research and Public Health, v. 9, n. 11, p. 3770-3778, 2012.

WHITE, Emma V.; GATERSLEBEN, Birgitta. Greenery on residential buildings: Does it affect preferences and perceptions of beauty? Journal of Environmental Psychology, v. 31, n. 1, p. 89-98, 2011.

YANG, Feng; YUAN, Feng; QIAN, Feng; ZHUANG, Zhi; YAO, Jiawei. Summertime thermal and energy performance of a double-skin green facade: A case study in Shanghai. Sustainable Cities and Society, v. 39, n. February, p. 43-51, 2018.

\section{About the authors}

\section{Olavo Avalone Neto}

Assistant professor at the Federal University of Santa Maria, develops research on environmental psychology, social urban design, and public spaces cognition and creation processes.

ORCID 0000-0002-2862-8399

\section{Saori Kihara}

Cost Supervisor at NTT Facilities in Japan. She graduated from the Department of Architecture and Urban Science of Chiba University, where she researched environmental perception and cognition.

\section{Jun Munakata}

Professor at the Department of Architecture and Urban Science of Chiba University. His research focuses on environmental psychology and visual environment. 